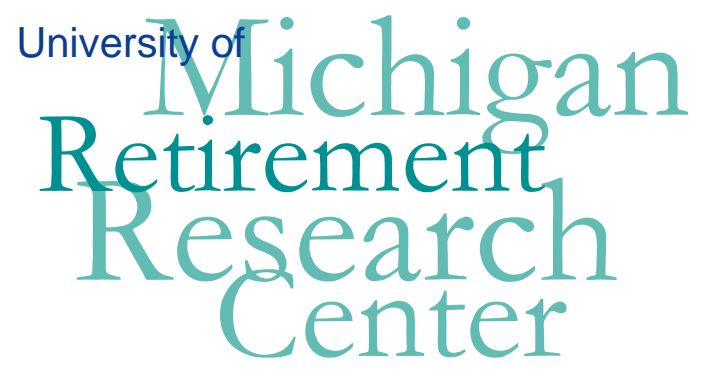

Working Paper WP 2008-201

\title{
How Much Do Respondents in the Health and Retirement Study Know About Their Tax-deferred Contribution Plans? A Cross- cohort Comparison
}

Irena Dushi and Marjorie Honig

\begin{tabular}{|l|l|}
\hline $\mathrm{M}$ & $\mathrm{R}$ \\
\hline $\mathrm{R}$ & $\mathrm{C}$ \\
\hline
\end{tabular}$\quad$ Project \#: UM08-05 



\title{
How Much Do Respondents in the Health and Retirement Study Know About Their Tax-deferred Contribution Plans? A Cross- cohort Comparison
}

\author{
Irena Dushi \\ Social Security Administration \\ Marjorie Honig \\ Hunter College and CUNY
}

December 2008
Michigan Retirement Research Center
University of Michigan
P.O. Box 1248
Ann Arbor, MI 48104
http://www.mrrc.isr.umich.edu/
(734) 615-0422

\section{Acknowledgements}

This work was supported by a grant from the Social Security Administration through the Michigan Retirement Research Center (Grant \# 10-P-98362-5-04). The findings and conclusions expressed are solely those of the author and do not represent the views of the Social Security Administration, any agency of the Federal government, or the Michigan Retirement Research Center.

Regents of the University of Michigan

Julia Donovan Darrow, Ann Arbor; Laurence B. Deitch, Bingham Farms; Olivia P. Maynard, Goodrich; Rebecca McGowan, Ann Arbor; Andrea Fischer Newman, Ann Arbor; Andrew C. Richner, Grosse Pointe Park; S. Martin Taylor, Gross Pointe Farms; Katherine E. White, Ann Arbor; Mary Sue Coleman, ex officio 


\title{
How Much Do Respondents in the Health and Retirement Study Know About Their Tax-deferred Contribution Plans? A Cross- cohort Comparison
}

\author{
Irena Dushi and Marjorie Honig
}

\begin{abstract}
We use information from Social Security earnings records to examine the accuracy of survey responses regarding participation in tax-deferred pension plans. As employer-provided defined benefit pensions are replaced by voluntary contribution plans, employees' understanding of the link between their annual contribution decisions and their post-retirement wealth is becoming increasingly important. We examine the extent to which wage-earners in the Health and Retirement Study correctly report their inclusion in tax-deferred contribution plans and, conditional on inclusion, their annual contributions. We use two samples representing different cohorts in two different periods: the original HRS cohort interviewed in 1992 at ages 51-61, and a combination of the War Babies and Early Baby Boomer cohorts at the same ages interviewed twelve years later. Our findings indicate that while respondents interviewed in 2004 were more likely to report correctly whether they were included in DC plans, they were no more accurate in reporting whether they contributed to their plans than respondents interviewed in 1992. Respondents in both cohorts, moreover, overestimated their annual contributions. In both 1992 and in 2004, the mean absolute difference between respondent-reported and Social Security earnings record contributions was 1.5 times larger than the mean earnings record contribution.
\end{abstract}

\section{Author Acknowledgements}

We thank Alan Gustman for helpful discussions regarding pension data in the Health and Retirement Study. 


\section{How Much Do Respondents in the Health and Retirement Study Know About Their Tax- deferred Contribution Plans? A Cross-cohort Comparison}

\section{Introduction}

There is by now a persuasive body of evidence indicating that many employed respondents in the original Health and Retirement Study cohort, responding in 1992 and in later interviews to questions regarding their defined benefit pensions, were not well informed about important aspects of these pensions such as the value of employer benefits at retirement and the age of eligibility for benefits. ${ }^{1}$ These findings were a matter of concern because of the important role that defined benefit pensions represented in the post-retirement wealth of this cohort.

Less attention has been given to the accuracy of information regarding defined contribution plans. The only study to date on these plans (Gustman and Steinmeier 2004) compares respondent reports of plan accumulations to values derived from employers’ pension plan descriptions submitted to the Department of Labor. Findings indicate substantial differences between respondent-reported plan values and plan accumulations calculated from plan descriptions. The authors conclude that in plans that do not have provision for voluntary employee contributions, accumulations calculated from employer plan descriptions provide a more accurate measure of the true value of the pensions; in defined contribution plans with voluntary contributions such as 401(k)-type plans, however, the single contribution rate reported

\footnotetext{
${ }^{1}$ Gustman and Steinmeier (2004, 2005), Chan and Stevens (2003). Mitchell (1988) and Gustman and Steinmeier (1989) reach similar conclusions using data from the 1983 Survey of Consumer Finances.
} 
in employers' plans may not reflect contribution rates in effect either prior to or after submission of the plan document. ${ }^{2}$

We use Social Security W-2 records, which contain information on earnings and taxdeferred contributions to 401(k)-type plans, to examine employees' knowledge of their defined contribution pensions. This issue is important because, from a public policy perspective, employees' decisions regarding their annual contributions play the decisive role in determining their pension wealth at retirement. We examine employee tax-deferred contributions to defined contribution pensions, the most common of which are 401(k)-type plans. ${ }^{3}$ We compare the accuracy of information reported in 1992 by respondents ages 51-61 in the original HRS cohort (born 1931-41) with information reported in 2004 by respondents ages 51-61 representing two younger cohorts, the War Babies (WB) and Early Baby Boomer (EBB) cohorts (referred to hereafter as the WB/EBB cohort). ${ }^{4}$ Respondents in these two younger cohorts, born in 1942-47 and 1948-53 respectively, are more likely to be enrolled in defined contribution plans ${ }^{5}$ and accumulations in their accounts are likely to represent a larger share of their post-retirement wealth. Our expectation, therefore, is that they would be better informed about their plans than members of the older cohort. We test this assumption by first comparing respondent reports of inclusion in defined contribution plans with evidence from $\mathrm{W}-2$ records. We then compare reports of annual contributions to such plans with values obtained from these records. To our knowledge, this analysis is the first to use the information in $\mathrm{W}-2$ records to assess the reliability

\footnotetext{
${ }^{2}$ In both types of plans, moreover, mismatches may occur in the process of linking employers with HRS respondents (Rohwedder 2003).

${ }^{3}$ In addition to 401(k)s, these plans include 403(b), thrift and savings plans, and Salary Reduction Agreements (SRAs). A detailed discussion of these plans appears in Engelhardt (2001).

${ }^{4}$ Among employees ages 51-61 reporting defined contribution pensions in 1992, 69 percent specified 401(k)-type plans; among respondents in the combined WB and EBB cohorts (WB/EBB cohort) reporting defined contribution plans in 2004, 79 percent specified 401(k)-type plans.

${ }^{5}$ Among respondents in these cohorts reporting coverage under a single pension plan in 2004, 61 percent were covered by defined contribution plans, compared to 41 percent among HRS respondents in 1992.
} 
of employee reports regarding inclusion in defined contribution plans and annual tax-deferred contributions. ${ }^{6}$

We find that respondents in the WB/EBB cohort were more accurate than those in the HRS cohort in reporting inclusion in DC plans. They were not more accurate in their responses regarding whether they were currently contributing to their plan, however. Respondents in both cohorts, moreover, significantly overestimated their annual contributions.

The following section describes survey information from the Health and Retirement Study regarding coverage and participation in employer-provided defined contribution pension plans and Social Security administrative record data on tax-deferred contributions to defined contribution plans. The next section uses these two sources of information to assess the accuracy of reporting regarding inclusion in DC plans, whether there were contributions to plans, and, if so, the amounts of these contributions. A final section summarizes our findings about similarities and differences between the two cohorts.

\section{Data}

We use data from the Health and Retirement Study (HRS), a longitudinal, nationally representative survey of older Americans over the age of 50 and their spouses of any age. The first wave of interviews was conducted in 1992 and follow-up interviews were conducted every other year thereafter. In this analysis, we use the 1992 and 2004 waves of the survey. We restrict our samples to respondents ages 51-61: the original HRS cohort born 1931-41 who were interviewed in 1992, and the War Babies (WB) and Early Baby Boomers (EBB) cohorts born

\footnotetext{
${ }^{6}$ Cunningham and Engelhardt (2002) use W-2 records of the original HRS cohort to examine the responsiveness of 401(k) saving to taxation and employer matching, but do not examine the accuracy of self-reported information. A recent study (Bricker and Engelhardt 2007) uses W-2 record information to examine measurement error in reported earnings among the three cohorts in the Health and Retirement Study.
} 
1942-47 and 1948-53, who were interviewed in 2004. ${ }^{7}$ The Health and Retirement Study provides extensive information on demographic and job characteristics, household income and wealth, pension plans in current and previous job(s), attitudes toward risk, financial planning horizons, retirement plans, and expectations about the future.

The pension section begins with a question regarding whether respondents are included in one or more pension plans through their job or union, and if so, whether these plans are defined benefit (DB) or defined contribution (DC) pensions. ${ }^{8}$ Respondents who report being included in a defined contribution plan are then asked a series of questions pertinent to the plan, such as the type of plan (whether 401(k), 403(b), SRA, for example), the account balance and how it is invested, whether the plan allows investment choice, and whether the employer offers a matching contribution. In addition, respondents are asked about the amounts they are currently contributing (either a dollar amount or as a percent of pay) to their accounts and the frequency of such contributions. We use this information to calculate their annual contributions.

An important feature of this dataset is that respondents were asked either in 1992, 1998, or 2004 to give permission for their Social Security benefits and earnings records to be linked to their survey information. ${ }^{9}$ For the original HRS respondents who consented in 1992, earnings records are available from 1980-1991, whereas for those of the same cohort who consented in

\footnotetext{
${ }^{7}$ Appendix Table 1 maps each of these cohorts as they enter the survey. In the following discussion, we refer to the WB/EBB sample as a single cohort.

${ }^{8} \mathrm{DB}$ plans are funded by employers and provide retirement benefits based on a formula typically involving the final salary, age, and years of service. In contrast, DC plans are tax-deferred savings accounts in which employee contributions and investment returns are deferred from taxes until account balances are drawn down. Employers may also elect to contribute a fixed proportion of employees' pay with pre-tax dollars.

${ }^{9}$ Members of the HRS cohort were initially asked for permission in 1992. Additional permissions were obtained in 1994 and 1996 [see Olson (1999) and Mitchell, Olson, and Steinmeier (2000) for discussions of these data]. In our analysis, we refer to all 1992, 1994, and 1996 consenters as 1992 consenters. Respondents in the HRS cohort were asked to give permission again in 2004. Members of the WB cohort were initially asked for permission in 1998 and those who refused were asked again in 2004. Members of the EBB cohort were asked to give consent at the time when they entered the survey in 2004.
} 
2004, earnings records are available from $1978-2003 .{ }^{10}$ For respondents in the WB/EBB cohort who consented in 2004, earnings records are available from 1978-2003. Appendix Table 2 shows the overall samples of respondents ages 51-61 in each cohort who consented to the release of their administrative records, by permission year.

\section{Social Security earning records}

Social Security earnings records contain information collected from the Internal Revenue Service Form W-2 that employers file to report salaries and benefits paid to employees. The dataset provides annual information on total compensation subject to federal income taxation (which includes wages, tips and other compensation), earnings that are subject to the Social Security payroll tax (FICA), referred to as covered earnings, earnings that are not subject to FICA (uncovered earnings), self-employment taxable income, and tax-deferred contributions to employer-sponsored retirement accounts. ${ }^{11}$ As stipulated in the Internal Revenue Code, as of 1984, employee contributions (both mandatory and voluntary) to tax-deferred retirement plans are excluded from federal income tax in the year of contribution, but are subject to Social Security (FICA) payroll tax. Beginning in 1990, the amount of the tax-deferred contribution is reported in a separate field in the $\mathrm{W}-2$ record. This field is not included in the HRS restricted data file for 1992 consenters, but it is included for respondents consenting in 1998 and 2004. Thus, for 1992 consenters with earnings below the Social Security taxable maximum, we

\footnotetext{
${ }^{10}$ For those HRS respondents who gave consents both in 1992 and 2004, we use earnings records from the latter consent.

${ }^{11}$ See Pattison and Waldron (2008) and Utendorf (1999) for further discussion of the Social Security’s administrative data.
} 
calculate the amount of the tax-deferred contribution ${ }^{12}$ as the difference between FICA earnings and total compensation. ${ }^{13}$

As noted above, respondents were asked at the interview about the amounts they currently contribute to their accounts and the frequency of their contributions. From these reports, we calculate an annual contribution for the interview year. Information on tax-deferred contributions in $\mathrm{W}-2$ records is available only up to the year prior to the interview year in which respondents gave consents. Thus, for HRS respondents, we use $1991 \mathrm{~W}-2$ record contributions and for the WB/EBB cohort, we use $2003 \mathrm{~W}-2$ contributions. ${ }^{14}$ This procedure may introduce measurement error if respondents' contributions differ between the two years. To estimate the extent of this potential bias, we compare 1991 and 1992 W-2 contributions for the subsample of HRS respondents (401 cases) who gave consents in 2004 and for whom we have both the 1991 and $1992 \mathrm{~W}-2$ contributions. At the means, the $1991 \mathrm{~W}-2$ contribution $(\$ 4,321)$ is not significantly different from the $1992 \mathrm{~W}-2$ contribution $(\$ 4,218)$. We thus conclude that our use of $\mathrm{W}-2$ record information for the year prior to the interview is unlikely to introduce significant measurement error. $^{15}$

\footnotetext{
12 The Social Security taxable maximum was $\$ 53,400$ in 1991 and $\$ 87,000$ in 2003 . The maximum annual contribution in a tax-favored account was $\$ 8,475$ in 1991 and $\$ 12,000$ in 2003, with provision in the latter year for an additional contribution of $\$ 2,000$ for individuals ages 50 and above.

${ }^{13}$ In the Social Security earnings records, FICA earnings are reported up to the Social Security maximum taxable earnings. Among covered workers in the U.S., 5.5 percent had annual earnings exceeding the Social Security taxable maximum (Social Security Administration 2007) in both 1991 and 2003. In our sample of workers ages 51-61 with matched Social Security W-2 records, about one percent of respondents in the HRS and WB/EBB cohorts had earnings above the Social Security taxable maximum in 1991 and 2003. We exclude respondents whose total compensation is above the total maximum because we cannot calculate their tax-deferred contributions. In addition, a substantial proportion of state and local government workers participating in tax-deferred contribution plans are exempt from FICA payroll taxes and thus their tax-deferred contributions cannot be calculated (Cunningham and Engelhardt 2002). In our sample, less than two percent of respondents were state and local government workers, as indicated in W-2 records. In addition, seven percent of respondents in our samples in both 1992 and 2004 reported their jobs to be in public administration. We exclude both groups from our analysis.

${ }^{14}$ Earnings records are not available for 2003 for respondents in the WB cohort who gave consents in 1998; we thus exclude them from our analysis.

${ }^{15}$ Previous research suggests that relatively few employees change their contribution rates over time. Kusko, Poterba, and Wilcox (1998), analyzing individual contribution data from a large 401(k) plan, find that most workers did not change their contribution rates from one year to the next year. Madrian and Shea (2001) and Choi et al.
} 


\section{Comparing respondent reports with $\mathrm{W}-2$ record information}

\subsection{Inclusion in a pension plan and identification of pension type}

We first compare respondents' reports of whether they were included in a pension plan and if so, the type of the plan, with information on tax-deferred contributions in W-2 records. This comparison provides a measure of the relative degree of misreporting by respondents of inclusion in defined contribution pensions in the HRS and WB/EBB cohorts. Our samples consist of respondents with matched SSA records who were asked whether they were included in a pension plan. Table 1 compares these responses with an indicator generated from the matched $\mathrm{W}$-2 records of whether the respondents had made a tax-deferred contribution in the previous year, indicating inclusion in a DC plan. ${ }^{16}$ Panel A reports frequencies, panels B and C, column and row percents, and Panel D, cell proportions.

Panel B indicates that among respondents with positive W-2 contributions in the previous year (col. 1 and 4), 69 percent of respondents in the HRS cohort and 82 percent in the WB/EBB cohort correctly reported having a DC plan only or both a DC and DB plan. The accuracy rate in the more recent $\mathrm{WB} / \mathrm{EBB}$ cohort is significantly higher (at the 1 percent level) than that of the earlier cohort.

Panel C provides information regarding the proportion of respondents in each cohort, by plan type, who contributed to their plans in the previous year. Among those who reported being included in a DC plan only, W-2 records confirm that 61 percent of the HRS cohort and 68 percent of the WB/EBB cohort contributed to their plans in the previous year. Comparable rates for respondents reporting inclusion in both a DC and a DB plan are 56 percent in the HRS cohort

(2002) find that the majority of 401(k) participants who were hired in firms with automatic enrollment maintained the default contribution rate for at least 15 months and 3 years, respectively.

16 The absence of a contribution in a given year does not necessarily imply that the respondent is not included in a DC plan, however. 
and 71 percent in the WB/EBB cohort. ${ }^{17}$ Finally, it is worth noting that among respondents consenting to the release of their $\mathrm{W}-2$ records, a significantly higher proportion of respondents in the WB/EBB cohort than in the HRS cohort made a contribution to a DC plan (42 percent compared to 33 percent). ${ }^{18}$

\subsection{Contributions to DC plans}

We now use the information on tax-deferred contributions in W-2 records to examine the accuracy of respondent reports regarding whether they made contributions to their plans. Our samples consist of the respondents in Table 1 who reported that they were included in a DC plan only or both DC and DB plans. Table 2 reports the joint distributions of tax-deferred contributions (whether positive or zero) as reported by respondents and as indicated in W-2 records. Panel B indicates that nearly identical proportions of respondents in the HRS and WB/EBB cohorts (70 and 71 percent) reported either a positive or zero contribution consistent with $\mathrm{W}-2$ records. In the HRS cohort, 53 percent of the sample correctly identified a positive contribution and 17 percent a zero contribution; in the WB/EBB cohort, 62 percent accurately identified a positive contribution and nine percent a zero contribution.

Among respondents who reported positive contributions, a substantial proportion in each cohort (25 and 20 percent respectively) did not make a contribution, according to $\mathrm{W}$-2 records (Panel C). This finding suggests that respondents' projections of their DC wealth at retirement are likely to be over-estimates of their realized wealth. Finally, Table 2 provides information on the proportions of respondents who in fact contributed to their plans in the year prior to the

\footnotetext{
${ }^{17}$ The latter rate is unreliable due to the small sample.

18 This difference is significant at the 1 percent level. These rates are similar to those in Buessing and Soto (2006). Using Form 5500 data from the Department of Labor, the authors find that among all private sector wage and salary workers, participation rates in DC plans were 33 percent in 1991 and 45 percent in 2003 (Table E4).
} 
interview according to W-2 records. Columns 1 and 4 indicate that among respondents with matched W-2 records who reported that they were included in DC plans, only 60 percent in the HRS cohort and 69 percent in the WB/EBB cohort had positive contributions in W-2 records. ${ }^{19}$ These relatively low participation rates may reflect respondent misidentification of plans as DC plans. ${ }^{20}$ Among respondents in the HRS cohort who did not contribute to their DC plans in 1991, 88 percent had not contributed in any of the previous five years; in the WB/EBB cohort, 61 percent had not contributed in the previous five years. This pattern suggests that plan misreporting may be widespread among respondents in the Health and Retirement Study.

Alternatively, low participation rates may reflect respondents' decisions not to contribute to their plans on a regular basis. Respondents' contribution patterns, however, do not fit this model. Among respondents in the HRS cohort who did not make a contribution in 1991, only six percent had contributed in 1990; among respondents in the WB/EBB cohort who had not contributed to their plans in 2003, only 18 percent had contributed in the previous year.

Consistent contribution patterns are also evident among respondents who had contributed to their plans in 1991 or 2003. Among HRS respondents who contributed in 1991, only 22 percent had not contributed in 1990; among WB/EBB respondents contributing in 2003, only nine percent had not contributed in 2002. These findings reveal systematic contribution patterns that support the alternative explanation of respondent misreporting of plan type. Additional evidence is provided by examining five-year contribution patterns among respondents who had positive contributions in W-2 records in the year prior to being interviewed

\footnotetext{
${ }^{19}$ Honig and Dushi (2003) find comparable rates using 1993 CPS data. Among full-time private sector wage and salary workers, 63 percent of men and 66 percent of women who reported that they had 401(k) accounts said they planned to contribute to their accounts during the interview year.

${ }^{20}$ We define the participation rate as the proportion of respondents included in DC plans who make a contribution to their plan in a given year. This definition follows that of Andrea L Kusko, James M. Poterba and David M. Wilcox (1998); see, however, Turner et al (2003) for alternative measures.
} 
and can therefore be identified as being enrolled in DC plans at that time. In the HRS cohort, 33 percent of respondents who had made contributions in 1991 had contributed in each of the preceding five years; in the $\mathrm{WB} / \mathrm{EBB}$ cohort, 61 percent of respondents who had made contributions in 2003 had contributed in each of the preceding five years. This evidence suggests that the potential for respondent misreporting of plan type should be taken into consideration when survey information is used to evaluate the role of pensions in retirement outcomes. $^{21}$

\subsection{Contribution amounts: Self-reported values and W-2 record information}

In the previous section, we examined the accuracy of respondents' reports regarding whether they had contributed to a DC plan in the previous year. We now turn to a comparison of self-reported contribution values with amounts reported in $\mathrm{W}-2$ records among respondents who indicated that they were included in DC plans and for whom both self-reported and W-2 contribution information is available (Table 3). ${ }^{22}$ Columns 1, 2, 4 and 5 report univariate distributions of annual self-reported and W-2 contributions. Columns 3 and 6 report distributions of the difference between self- and W-2-reported contributions measured at the individual level.

Table 3 indicates that among respondents in the HRS cohort, self-reported contributions exceed W-2 record contributions throughout the two distributions (columns 1 and 2). At the medians, the self-reported contribution $(\$ 1,825)$ is nearly twice as large as the $\mathrm{W}-2$ contribution (\$945). At the means, the self-reported contribution is $\$ 2,774$ compared to the $\mathrm{W}-2$ contribution

\footnotetext{
${ }^{21}$ See Gustman and Steinmeier (2004) for a comprehensive discussion of plan type misreporting.

${ }^{22}$ As discussed above, samples in these tables exclude respondents with W-2 earnings above the Social Security taxable maximum. Respondents with W-2 tax-deferred contributions above the maximum amount allowed are also excluded from the sample due to the likelihood of employer reporting error. The sample of respondents in the HRS cohort consists of those who gave consents to release W-2 record information either in 1992 or 2004.
} 
of $\$ 1,974$. This difference of $\$ 800$ is statistically significant at the 1 percent level and is 41 percent of the mean W-2 contribution. In the WB/EBB cohort, self-reported contributions similarly exceed W-2 contributions (columns 4 and 5). At the medians, the self-reported contribution $(\$ 2,328)$ is 79 percent larger than the $\mathrm{W}-2$ contribution $(\$ 1,300)$. The difference in mean values of $\$ 927$, or 36 percent of the mean $\mathrm{W}-2$ contribution of $\$ 2,579$, is significant at the 1 percent level.

Columns 3 and 6 in Table 3 present distributions of the difference between self-reported and $\mathrm{W}-2$ contributions at the individual level. Column 3 indicates that there are substantial differences in the HRS cohort, ranging from $-\$ 810$ at the $10^{\text {th }}$ percentile (self-reported less than $\mathrm{W}-2$ contribution) to $\$ 3,537$ at the $90^{\text {th }}$ percentile. Similarly, in the WB/EBB cohort (col. 6), the difference increases from $-\$ 950$ at the $10^{\text {th }}$ percentile to $\$ 3,830$ at the $90^{\text {th }}$ percentile. In both cohorts, reporting errors are substantial at the means, but not at the medians. The pattern of error is a matter of concern for public policy: 50 percent of respondents report contribution values that are considerably larger than their actual contributions. The magnitude of the reporting errors suggests that conclusions drawn from survey information alone are likely to result in upwardbiased estimates of participation rates and contribution amounts.

We now assess the degree of accuracy in reporting annual contributions among respondents who said they were included in a DC plan and whose $\mathrm{W}-2$ records indicate a positive contribution in the year prior to the interview (Table 4). Self-reported contributions of respondents in this sample may be either positive or zero. Respondents with positive contributions in W-2 records, representing 60 percent of respondents in the HRS cohort and 69 percent in the WB/EBB cohort, as reported above, are considerably more accurate than respondents in the broader samples reported in Table 3. In the HRS cohort, the difference at the 
means between self-reported and W-2 record contributions is $\$ 241$ in this more selective sample, compared to $\$ 800$ in the broader sample; in the WB/EBB cohort, comparable values are $\$ 647$ and $\$ 927$ respectively. Among respondents in the HRS cohort, self-reported and W-2 values (columns 1 and 2) are remarkably similar throughout the two distributions, a difference of about $\$ 200$ up to and including the $75^{\text {th }}$ percentile, increasing to $\$ 570$ at the $90^{\text {th }}$ percentile. A somewhat different pattern emerges among respondents in the WB/EBB cohort (columns 5 and 6). The difference between self-reported and W-2 contributions increases monotonically from $\$ 16$ at the $10^{\text {th }}$ percentile to $\$ 1,508$ at the $90^{\text {th }}$ percentile.

As in Table 3, columns 3 and 7 compare self-reported and W-2 contributions for the same individual. At the medians, the differences between self-reported and W-2 record contributions in the HRS and WB/EBB cohorts are negligible ( $\$ 42$ and $\$ 84$ respectively). At the means, the difference between self-reported and W-2 contributions is significantly larger in the WB/EBB cohort (\$647) than in the HRS cohort (\$241). In both cohorts, the differences between selfreported and W-2 contributions in the lower (upper) quartiles of the distributions in Table 4 are larger (smaller) than the respective differences in the broader sample (Table 3).

Columns 4 and 8 present distributions of the reporting error measured as the ratio of the absolute difference in contributions (self-reported minus W-2 contribution) relative to the W-2 record contribution. In both cohorts, the relative reporting error increases systematically from approximately one-half of the $\mathrm{W}-2$ contribution at the $10^{\text {th }}$ percentile to more than twice the $\mathrm{W}-2$ contribution at the $90^{\text {th }}$ percentile. Thus, while the mean difference between self-reported and $\mathrm{W}-2$ contributions is significantly larger in the $\mathrm{WB} / \mathrm{EBB}$ cohort, the reporting error relative to W-2 contributions is similar to that in the HRS cohort. 
Finally, Table 4 reveals that both self-reported and $\mathrm{W}-2$ record contributions are significantly larger in the WB/EBB cohort than in the earlier HRS cohort. The mean selfreported contribution in the WB/EBB cohort is $\$ 4,306$ compared to $\$ 3,497$ in the HRS cohort (difference significant at the 1 percent level). W-2 record contributions in the WB/EBB cohort are \$3,656 at the mean compared to \$3,256 in the HRS cohort (difference significant at the 5 percent level).

Table 5 provides an additional measure of the accuracy of respondents’ reports of annual contributions using the same sample as in Table 4 (respondents with positive contributions in W2 records). We classify respondents by an alternative measure of reporting accuracy: whether their reported contributions are within plus or minus 25 percent of their $\mathrm{W}$-2 record contributions. The reported contributions of roughly one-half of respondents in both cohorts (51 and 49 percent, respectively) fall within this category. Approximately one-third of respondents over-reported their contributions by more that 25 percent of their W-2 contributions and 15 percent under-reported by more than 25 percent. Small proportions in both cohorts report zero contributions when $\mathrm{W}-2$ records indicate a positive contribution.

\subsection{Multivariate analysis of reporting error}

Table 6 reports regression estimates of the relationship between the relative magnitude of the error in respondents' reports of contribution amounts and a number of demographic, job, and plan characteristics, earnings and household wealth, financial planning and risk aversion measures, and expected years to retirement. ${ }^{23}$ We measure reporting error as the absolute value

\footnotetext{
${ }^{23}$ Sample means appear in Appendix Table 3. Compared to the HRS cohort, respondents in the WB/EBB cohort are younger, better educated, less risk averse, have longer planning horizons, and expect to retire at later ages. They hold larger DC account balances but their mean household wealth is identical to that of the HRS cohort.
} 
of the difference between self-reported and $\mathrm{W}$-2 record contributions relative to the larger of the two values. ${ }^{24}$

Estimates in columns 1 and 3 indicate that respondents in both cohorts who may choose how their contributions are invested are significantly better informed about their annual contribution amounts. In neither cohort, moreover, is the reporting error systematically related to demographic or job-related characteristics. ${ }^{25}$ In all remaining measured characteristics, however, the two cohorts differ substantially. Among respondents in the HRS cohort, the reporting error regarding the amount of contributions is larger, the longer the expected time to retirement. Employees in this cohort who do not expect to retire within 12 years have a 14 percent larger reporting error than those who expect to retire within 6 years. Expected time to retirement does not play a role in the decisions of members of the WB/EBB cohort, however. In the HRS cohort, moreover, reporting error is correlated with the size of account balances (the error is smaller for accounts of $\$ 10,000$ or more), but this factor is not important in the WB/EBB cohort. Overall, the adjusted $\mathrm{R}^{2}$ in each of these regressions is small (.03 and .07 in the HRS and WB/EBB cohorts respectively), indicating that explanatory variables jointly explain relatively little of the reporting error related to contributions to DC plans.

Column 5 in Table 6 examines determinants of the relative size of the reporting error on a pooled sample of the two cohorts. While holding IRA/Keogh accounts is not systematically related to the accuracy of reports in the individual cohorts, it is associated with substantially lower reporting error in the larger sample. In addition, the reporting error of respondents in the second wealth quartile is significantly larger than that of respondents in the first quartile in the

\footnotetext{
${ }^{24}$ Using this measure, the ratio of the numerator (the absolute difference) to the denominator does not vary among respondents with the same absolute difference depending on whether their self-reported or W-2 contribution is larger.

${ }^{25}$ The exception is white-collar workers in the WB/EBB cohort, who have a marginally smaller reporting error relative to blue-collar workers.
} 
larger sample. Finally, there may be unobserved differences between the two cohorts related to a smaller reporting error in the WB/EBB cohort, indicated by the marginally significant negative coefficient on the cohort indicator.

\section{Conclusion}

We utilize information in Social Security Administration W-2 earnings records to examine how accurately respondents in the Health and Retirement Study report their inclusion in defined contribution pension plans and their annual contributions to these plans. We ask whether more recent cohorts of respondents, whose participation rates in defined contribution plans are significantly higher than those of earlier cohorts, are better informed. We use two samples representing the original HRS cohort interviewed in 1992 at ages 51-61 and a combination of the War Babies and Early Baby Boomer cohorts at the same ages interviewed twelve years later.

Our findings indicate that respondents interviewed in 2004 were more likely to report correctly whether they were included in DC plans, but were not more accurate in reporting whether they currently contributed to their plans than those interviewed in 1992. Respondents in both cohorts who contributed to their plans significantly overestimated their annual contributions. While the reporting error measured as the difference between respondents' selfreported and W-2 contributions is larger in the WB/EBB cohort, the absolute error relative to the $\mathrm{W}-2$ contribution is the same in the WB/EBB cohort as in the HRS cohort (1.52 and 1.44 at the means respectively). The magnitude of this error is of particular concern for public policy because balances in defined contribution plans may constitute for many employees, especially those in the more recent cohort, the largest component of their retirement wealth. Our 
conclusions thus substantiate ongoing efforts, both public and private, to increase saving in taxdeferred pensions and to enhance financial literacy in the general population. 


\section{References}

Bricker, Jesse and Gary V. Engelhardt. 2007. "Measurement Error in Earnings Data in the Health and Retirement Study.” Center for Retirement Research at Boston College Working Paper 2007-16.

Buessing, Marric and Mauricio Soto. 2006. “The State of Private Pensions: Current 5500 Data.” Center for Retirement Research at Boston College, Issue Brief, February, Number 42.

Chan, Sewin and Ann Huff Stevens. 2003. "What You Don’t Know Can’t Help You: Knowledge and Retirement Decision Making.” NBER Working Paper 10185.

Choi, James., David Laibson, Brigitte C. Madrian, and Andrew Metrick. 2002. "Defined Contribution Pensions: Plan Rules, Participant Choices, and the Path of Least Resistance.” In Tax Policy and the Economy, edited by James M. Poterba. Cambridge, Ma.: MIT Press.

Cunningham, Christopher R., and Gary V. Engelhardt. 2002. "Federal Tax Policy, Employer Matching, and 401(k) Saving: Evidence from HRS W-2 Records.” National Tax Journal Vol. LV, No. 3, (September 2002): 617-645.

Engelhardt, Gary V. 2001 "Have 401(k)s Raised Household Saving? Evidence from the Health and Retirement Study.” Syracuse University. Mimeo.

Gustman, Alan L., and Thomas L. Steinmeier. 1989. "An Analysis of Pension Benefit Formulas, Pension Wealth and Incentives from Pensions.” Research in Labor Economics 10:53-106.

Gustman, Alan L., and Thomas L. Steinmeier. 2004. "What People Don’t Know About Their Pensions and Social Security.” In William G. Gale, John B. Shoven and Mark J. Warshawsky, editors, Private Pensions and Public Policies. Washington, D.C.: Brooking Institution: 57-119.

Gustman, Alan L., and Thomas L. Steinmeier. 2005. "Imperfect Knowledge of Social Security and Pensions.” Industrial Relations 44(2): 373-397.

Honig, Marjorie and Irena Dushi. 2003. "How Demographic Change Will Drive Benefits Design.” In Benefits for the Workplace of Tomorrow, Olivia S. Mitchell, David S. Blitzstein, Michael S. Gordon, and Judith F. Mazo (eds). Philadelphia: University of Pennsylvania Press, 2003: 58-88.

Kusko, Andrea L., James M. Poterba, and David W. Wilcox. 1998 “Employee Decisions with Respect to 401(k) Plans.” In Living with Defined Contribution Pensions: Remaking Responsibility for Retirement, edited by Olivia S. Mitchell and Sylvester J. Schieber 98112. Philadelphia, Pennsylvania: Pension Research Council, the Wharton School of the University of Pennsylvania, and the University of Pennsylvania Press. 
Madrian, Brigitte C., and Dennis F. Shea. 2001. "The Power of Suggestion: Inertia in 401(k) Participation and Saving Behavior.” Quarterly Journal of Economics 116(4): 1149-87.

Mitchell, Olivia S.. 1988. “Worker Knowledge of Pension Provisions.” Journal of Labor Economics 6(1): 28-39.

Mitchell, Olivia S., Jan Olson, and Thomas L. Steinmeier. 2000. "Social Security Earnings and Projected Benefits,” in Olivia S. Mitchell, P. Brett Hammond, and Anna M. Rappaport, eds., Forecasting Retirement Needs and Retirement Wealth (Philadelphia: University of Pennsylvania Press), pp. 327-360.

Olson, Janice A. 1999. "Linkages with Data from Social Security Administrative Records in Health and Retirement Study.” Social Security Bulletin, Vol. 62, No. 2: 73-85.

Pattison, David and Hilary Waldron. June 2008. "Trends in Elective Deferrals of Earnings from 1990-2001 in Social Security Administrative Data.” Social Security Administration. ORDP Research and Statistics Notes, No. 2008-03.

Rohwedder, Susann. 2003. "Measuring Pension Wealth in the HRS: Employer and SelfReports. Unpublished manuscript. RAND Corporation.

Social Security Administration. 2007. Annual Statistical Supplement to the Social Security Bulletin.

Turner, John, Leslie Muller, and Satyendra K. Verma. 2003. "Defining Participation in Defined Pension Plans.” Monthly Labor Review. Vol. 126 No. 8 , pp. 36-43.

Utendorf, Kelvin R. 1999. "Recent Changes in Earnings Distributions in the United States: Age and Cohort Effects.” Social Security Bulletin, Vol. 62, No. 2:14-29. 
Table 1. Respondent reports regarding inclusion in a pension plan and W-2 record information on tax-deferred contributions among respondents with matched SSA records

\begin{tabular}{|c|c|c|c|c|c|c|}
\hline \multirow[b]{3}{*}{ Self reported } & \multicolumn{3}{|c|}{ HRS Cohort (1992) } & \multicolumn{3}{|c|}{ WB/EBB Cohort (2004) } \\
\hline & \multicolumn{3}{|c|}{ Contribution in the $\mathrm{W}-2$ record is: } & \multicolumn{3}{|c|}{ Contribution in the $\mathrm{W}-2$ record is: } \\
\hline & Positive & Zero & Total & Positive & Zero & Total \\
\hline \multicolumn{7}{|c|}{ A. Self-reports of inclusion in a pension (number) } \\
\hline Not included in any pension & 82 & 1,251 & 1,333 & 22 & 265 & 287 \\
\hline \multicolumn{7}{|l|}{ Included by pension type } \\
\hline DB only & 324 & 760 & 1,084 & 43 & 104 & 147 \\
\hline DC only & 853 & 553 & 1,406 & 289 & 134 & 423 \\
\hline Both & 48 & 37 & 85 & 20 & 8 & 28 \\
\hline Don’t know & 8 & 34 & 42 & 3 & 6 & 9 \\
\hline Total & 1,315 & 2,635 & 3,950 & 377 & 517 & 894 \\
\hline \multicolumn{7}{|c|}{ B. Self-reports of inclusion in a pension (column percent) } \\
\hline Not included in any pension & 6 & 47 & 34 & 6 & 51 & 34 \\
\hline \multicolumn{7}{|l|}{ Included by pension type } \\
\hline DB only & 25 & 29 & 27 & 11 & 20 & 27 \\
\hline DC only & 65 & 21 & 36 & 77 & 26 & 36 \\
\hline Both & 4 & 1 & 2 & 5 & 2 & 2 \\
\hline Don’t know & 1 & 1 & 100 & 1 & 1 & 1 \\
\hline Total & 100 & 100 & 100 & 100 & 100 & 100 \\
\hline \multicolumn{7}{|c|}{ C. Self-reports of inclusion in a pension (row percent) } \\
\hline Not included in any pension & 6 & 94 & 100 & 8 & 92 & 100 \\
\hline \multicolumn{7}{|l|}{ Included by pension type } \\
\hline DB only & 30 & 70 & 100 & 29 & 71 & 100 \\
\hline DC only & 61 & 39 & 100 & 68 & 32 & 100 \\
\hline Both & 56 & 44 & 100 & 71 & 29 & 100 \\
\hline Don’t know & 19 & 81 & 100 & 33 & 67 & 100 \\
\hline Total & 33 & 67 & 100 & 42 & 58 & 100 \\
\hline \multicolumn{7}{|c|}{ D. Self-reports of inclusion in a pension (cell percent) } \\
\hline Not included in any pension & 2 & 32 & 34 & 2 & 30 & 32 \\
\hline \multicolumn{7}{|l|}{ Included by pension type } \\
\hline DB only & 8 & 19 & 27 & 5 & 12 & 16 \\
\hline DC only & 22 & 14 & 36 & 32 & 15 & 47 \\
\hline Both & 1 & 1 & 2 & 2 & 1 & 3 \\
\hline Don’t know & 0 & 1 & 1 & 0 & 1 & 1 \\
\hline Total & 33 & 67 & 100 & 42 & 58 & 100 \\
\hline
\end{tabular}

Notes : Authors' calculations using data from the Health and Retirement Study and Social Security earnings records. Samples consist of private sector wage and salary workers ages 51-61 in 1992 (HRS cohort) and 2004 (WB/EBB cohort) with matched SSA records. 
Table 2. Employee reports and W-2 record information on tax-deferred contributions among respondents who report being included in a DC plan

\begin{tabular}{|c|c|c|c|c|c|c|}
\hline \multirow[b]{3}{*}{ Self reported } & \multicolumn{3}{|c|}{ "HRS Cohort (1992) } & \multicolumn{3}{|c|}{ "WB/EBB Cohort (2004) } \\
\hline & \multicolumn{3}{|c|}{ Contribution in the $\mathrm{W}-2$ record is: } & \multicolumn{3}{|c|}{ Contribution in the $\mathrm{W}-2$ record is: } \\
\hline & Positive & Zero & Total & Positive & Zero & Total \\
\hline \multicolumn{7}{|c|}{ A. Self-reported contribution is (number): } \\
\hline Positive & 783 & 259 & 1,042 & 278 & 69 & 347 \\
\hline Zero & 36 & 255 & 291 & 3 & 40 & 43 \\
\hline Don't know & 82 & 76 & 158 & 28 & 33 & 61 \\
\hline Total & 901 & 590 & 1,491 & 309 & 142 & 451 \\
\hline \multicolumn{7}{|c|}{ B. Self-reported contribution is (cell perent): } \\
\hline Positive & 53 & 17 & 69 & 62 & 15 & 77 \\
\hline Zero & 2 & 17 & 20 & 1 & 9 & 10 \\
\hline Don't know & 5 & 5 & 11 & 6 & 7 & 14 \\
\hline Total & 60 & 40 & 100 & 69 & 31 & 100 \\
\hline \multicolumn{7}{|c|}{ C. Self-reported contribution is (row percent): } \\
\hline Positive & 75 & 25 & 100 & 80 & 20 & 100 \\
\hline Zero & 12 & 88 & 100 & 7 & 93 & 100 \\
\hline Don't know & 52 & 48 & 100 & 46 & 54 & 100 \\
\hline Total & 60 & 40 & 100 & 69 & 31 & 100 \\
\hline
\end{tabular}

Notes: Authors' calculations using data from the Health and Retirement Study and Social Security earnings records. Samples consist of private sector wage and salary workers ages 51-61 in 1992 and 2004, who report inclusion in at least a DC plan (either a DC plan only or both DC and DB plans) for whom a matched SSA record is available. 
Table 3. Distribution of tax-deferred contributions (in \$2003) as reported by respondents and in W-2 records among respondents for whom both self-reported and W-2 contributions are available (either zero or positive)

\begin{tabular}{|c|c|c|c|c|c|c|}
\hline \multirow[b]{3}{*}{ Percentiles } & \multicolumn{3}{|c|}{ HRS cohort (1992) } & \multicolumn{3}{|c|}{ WB/EBB cohort (2004) } \\
\hline & $\begin{array}{l}\text { Respondent } \\
\text { self-reported } \\
\text { contributions }\end{array}$ & $\begin{array}{l}\text { W-2 record } \\
\text { contributions }\end{array}$ & $\begin{array}{l}\text { Distribution of } \\
\text { the difference } \\
\text { in contributions }\end{array}$ & $\begin{array}{l}\text { Respondent } \\
\text { self-reported } \\
\text { contributions }\end{array}$ & $\begin{array}{l}\text { W-2 record } \\
\text { contributions }\end{array}$ & $\begin{array}{l}\text { Distribution of } \\
\text { the difference }^{\mathrm{a}} \\
\text { in contributions }\end{array}$ \\
\hline & $(1)$ & $(2)$ & (3) & (4) & (5) & (6) \\
\hline 10 & 0 & 0 & -810 & 0 & 0 & -950 \\
\hline 25 & 346 & 0 & -60 & 818 & 0 & -76 \\
\hline 50 & 1,825 & 945 & 36 & 2,328 & 1,300 & 221 \\
\hline 75 & 4,244 & 3,105 & 1,274 & 5,044 & 3,800 & 1,502 \\
\hline 90 & 7,192 & 5,940 & 3,537 & 9,312 & 7,300 & 3,830 \\
\hline Mean values & 2,774 & $1,974^{1}$ & 800 & 3,506 & $2,579^{1}$ & 927 \\
\hline St. dev. & 2,990 & 2,602 & 2,464 & 3,801 & 3,184 & 2,603 \\
\hline $\mathrm{N}$ of Obs & & 1,262 & & & 369 & \\
\hline
\end{tabular}

Notes: Authors' calculations using data from the Health and Retirement Study and Social Security earnings records. Samples consist of private sector wage and salary workers ages 51-61 who report being included in at least a DC plan and for whom both the self-reported and W-2 contributions are available (either zero or positive). These samples exclude respondents with earnings above the Social Security taxable maximum, and respondents with W-2 tax-deferred contributions above the maximum amount for the respective year. In both cohorts, self-reported contributions are as reported at the interview and W-2 contributions are from the previous year (1991 for the HRS cohort and 2003 for the WB/EBB cohort); see text discussion.

a The difference in contributions is measured as the respondent's self-reported minus W-2 record contribution.

${ }^{1}$ denotes that the difference at the means between self-reported and W-2 record contributions is significant at the 1 percent level in each cohort. 
Table 4. Distribution of tax-deferred contributions (in \$2003) among respondents with positive contributions in W-2 records

\begin{tabular}{|c|c|c|c|c|c|c|c|c|}
\hline \multirow[b]{3}{*}{ Percentiles } & \multicolumn{4}{|c|}{ HRS cohort (1992) } & \multicolumn{4}{|c|}{ WB/EBB cohort (2004) } \\
\hline & $\begin{array}{c}\text { Respondent } \\
\text { self-reported } \\
\text { contributions }\end{array}$ & $\begin{array}{l}\text { W-2 record } \\
\text { contributions }\end{array}$ & $\begin{array}{l}\text { Distribution of } \\
\text { the difference }^{\mathrm{a}} \\
\text { in contributions }\end{array}$ & $\begin{array}{c}\text { Distribution of } \\
\text { the ratio }^{\text {b }}\end{array}$ & $\begin{array}{c}\text { Respondent } \\
\text { self-reported } \\
\text { contributions }\end{array}$ & $\begin{array}{c}\text { W-2 record } \\
\text { contributions }\end{array}$ & $\begin{array}{l}\text { Distribution of } \\
\text { the difference }^{\mathrm{a}} \\
\text { in contributions }\end{array}$ & $\begin{array}{l}\text { Distribution } \\
\text { of the ratio }^{b}\end{array}$ \\
\hline & (1) & $(2)$ & (3) & (4) & (5) & (6) & (7) & (8) \\
\hline 10 & 629 & 675 & $-1,803$ & 0.47 & 616 & 600 & $-1,285$ & 0.55 \\
\hline 75 & 4,913 & 4,725 & 832 & 1.38 & 5,820 & 5,250 & 1,270 & 1.51 \\
\hline 90 & 7,860 & 7,290 & 2,469 & 2.40 & 10,258 & 8,750 & 3,384 & 2.52 \\
\hline Mean values & 3,497 & $3,256^{1}$ & 241 & 1.44 & 4,306 & $3,656^{1}$ & $647^{2}$ & 1.52 \\
\hline St. dev. & 2,919 & 2,645 & 2,078 & 1.99 & 3,979 & 3,230 & 2,616 & 2.02 \\
\hline
\end{tabular}

Notes: Authors' calculations using data from the Health and Retirement Study and Social Security earnings records. Samples consist of private sector wage and salary workers ages 51-61 who report being included in at least a DC plan and for whom W-2 contributions are positive whereas self-reported contributions are either positive or zero. These samples exclude respondents with earnings above the Social Security taxable maximum and respondents with W-2 tax-deferred contributions above the maximum amount for the respective year. In both cohorts, self-reported contributions are as reported at the interview and W-2 contributions are from the previous year (1991 for the HRS cohort and 2003 for the WB/EBB cohort).

${ }^{\mathrm{a}}$ The difference in contributions is measured as the respondent's self-reported minus W-2 record contribution.

${ }^{\mathrm{b}}$ The ratio is calculated as the absolute difference in contributions (self-reported minus W-2 record) relative to the W-2 record contribution.

${ }^{1}$ denotes that the difference at the means between self-reported and W-2 record contributions is significant at the 1 percent level in each cohort.

${ }^{2}$ denotes that the difference in the mean values between column 3 and 7 is significant at the 5 percent level. 
Table 5. Accuracy of self-reported contributions among respondents with positive contributions in $\mathrm{W}-2$ records

\begin{tabular}{ccccc}
\hline \hline \multirow{2}{*}{$\begin{array}{c}\text { Difference in contributions }{ }^{\text {a }} \text { relative to W-2 } \\
\text { contribution (\%) }\end{array}$} & HRS cohort (1992) & \multicolumn{2}{c}{ WB/EBB cohort (2004) } \\
\cline { 2 - 5 } & $\mathbf{N}$ & $\mathbf{\%}$ & $\mathbf{N}$ & $\mathbf{\%}$ \\
\hline Under report by more than 25\% & 113 & 15 & 36 & 14 \\
Report within plus/minus 25\% & 387 & 51 & 128 & 49 \\
Over report by more than 25\% & 231 & 30 & 93 & 36 \\
W-2 is positive and self-reported is zero & 34 & 4 & 3 & 1 \\
N of Obs & 765 & 100 & 260 & 100 \\
\hline
\end{tabular}

Note: See notes in Table 4.

${ }^{\mathrm{a}}$ The difference in contributions is measured as the respondent's self-reported minus W-2 record contribution. 
Table 6. Regression estimates of the relative reporting error of annual contributions among respondents with positive contributions in $\mathrm{W}-2$ records ${ }^{\mathrm{a}}$

\begin{tabular}{|c|c|c|c|c|c|c|}
\hline \multirow[b]{3}{*}{ Independent variables } & \multicolumn{2}{|c|}{ HRS cohort (1992) } & \multicolumn{2}{|c|}{ WB/EBB cohort (2004) } & \multicolumn{2}{|c|}{ Pooled } \\
\hline & Coefficient & Absolute t & Coefficient & Absolute t & Coefficient & Absolute t \\
\hline & $(1)$ & $(2)$ & (3) & $(4)$ & $(5)$ & $(6)$ \\
\hline Female & -0.014 & 0.45 & 0.017 & 0.44 & -0.005 & 0.19 \\
\hline $\begin{array}{l}\text { Age } \\
51-53 \text { (omitted) }\end{array}$ & & & & & & \\
\hline $\begin{array}{l}54-56 \\
57-61\end{array}$ & $\begin{array}{l}0.039 \\
0.039\end{array}$ & $\begin{array}{l}1.19 \\
1.12\end{array}$ & $\begin{array}{c}0.037 \\
-0.036\end{array}$ & $\begin{array}{l}0.99 \\
0.67\end{array}$ & $\begin{array}{l}0.030 \\
0.018\end{array}$ & $\begin{array}{l}1.21 \\
0.64\end{array}$ \\
\hline \multicolumn{7}{|l|}{$\begin{array}{l}\text { Race } \\
\text { White (omitted) }\end{array}$} \\
\hline $\begin{array}{l}\text { Black } \\
\text { Hispanic }\end{array}$ & $\begin{array}{c}0.058 \\
-0.055\end{array}$ & $\begin{array}{l}1.30 \\
1.10\end{array}$ & $\begin{array}{l}0.090 \\
0.069\end{array}$ & $\begin{array}{l}1.44 \\
0.90\end{array}$ & $\begin{array}{r}0.065^{*} \\
-0.031\end{array}$ & $\begin{array}{l}1.77 \\
0.75\end{array}$ \\
\hline \multicolumn{7}{|l|}{ Education } \\
\hline $\begin{array}{l}\text { Some college } \\
\text { College graduate }\end{array}$ & $\begin{array}{l}0.030 \\
0.035\end{array}$ & $\begin{array}{l}0.91 \\
0.92\end{array}$ & $\begin{array}{c}0.060 \\
-0.016\end{array}$ & $\begin{array}{l}1.38 \\
0.30\end{array}$ & $\begin{array}{l}0.040 \\
0.021\end{array}$ & $\begin{array}{l}1.50 \\
0.67\end{array}$ \\
\hline $\begin{array}{l}\text { Marital Status } \\
\text { Married }\end{array}$ & -0.011 & 0.32 & 0.008 & 0.19 & 0.001 & 0.03 \\
\hline \multicolumn{7}{|l|}{ Health Status } \\
\hline $\begin{array}{l}\text { Good } \\
\text { Excellent/very good }\end{array}$ & $\begin{array}{l}-0.032 \\
-0.018\end{array}$ & $\begin{array}{l}0.65 \\
0.37\end{array}$ & $\begin{array}{c}0.002 \\
-0.040\end{array}$ & $\begin{array}{l}0.03 \\
0.78\end{array}$ & $\begin{array}{l}-0.022 \\
-0.021\end{array}$ & $\begin{array}{l}0.59 \\
0.60\end{array}$ \\
\hline \multicolumn{7}{|c|}{ Financial planning horizon $^{b}$} \\
\hline $\begin{array}{l}2 \text { to } 5 \text { years } \\
\text { More than } 5 \text { years }\end{array}$ & $\begin{array}{l}-0.037 \\
-0.011\end{array}$ & $\begin{array}{l}1.00 \\
0.33\end{array}$ & $\begin{array}{l}0.033 \\
0.058\end{array}$ & $\begin{array}{l}0.60 \\
1.15\end{array}$ & $\begin{array}{c}-0.016 \\
0.012\end{array}$ & $\begin{array}{l}0.53 \\
0.42\end{array}$ \\
\hline \multicolumn{7}{|l|}{ Risk Aversion ${ }^{b}$} \\
\hline $\begin{array}{l}\text { Somewhat risk averse } \\
\text { Most risk averse }\end{array}$ & $\begin{array}{l}0.010 \\
0.037\end{array}$ & $\begin{array}{l}0.20 \\
0.83\end{array}$ & $\begin{array}{l}-0.079 \\
-0.095^{*}\end{array}$ & $\begin{array}{l}1.27 \\
1.63\end{array}$ & $\begin{array}{l}-0.014 \\
-0.009\end{array}$ & $\begin{array}{l}0.36 \\
0.25\end{array}$ \\
\hline \multicolumn{6}{|c|}{ Expected Years to Retirement ${ }^{b}$} & \\
\hline 7 to 12 years & 0.029 & 0.89 & -0.052 & 0.75 & 0.014 & 0.52 \\
\hline $\begin{array}{l}\text { More than } 12 \text { years } \\
\text { Never }\end{array}$ & $\begin{array}{l}0.144^{* * *} \\
0.066\end{array}$ & $\begin{array}{l}2.83 \\
1.19\end{array}$ & $\begin{array}{l}-0.104 \\
-0.021\end{array}$ & $\begin{array}{l}1.36 \\
0.32\end{array}$ & $\begin{array}{l}0.077^{*} \\
0.050\end{array}$ & $\begin{array}{l}1.91 \\
1.38\end{array}$ \\
\hline \multicolumn{3}{|c|}{ Blue-collar worker (omitted) } & & & & \\
\hline Managerial & 0.043 & 1.13 & 0.050 & 0.94 & 0.047 & 1.52 \\
\hline White-collar worker & -0.001 & 0.02 & $-0.083^{*}$ & 1.79 & -0.020 & 0.70 \\
\hline \multicolumn{7}{|l|}{ Tenure (years) } \\
\hline $6-15$ & 0.005 & 0.11 & 0.003 & 0.07 & 0.002 & 0.07 \\
\hline 16 or more & 0.023 & 0.56 & -0.068 & 1.30 & -0.010 & 0.32 \\
\hline
\end{tabular}


Table 6 (cont.)

\begin{tabular}{|c|c|c|c|c|c|c|}
\hline \multirow[b]{3}{*}{ Independent variables } & \multicolumn{2}{|c|}{ HRS cohort (1992) } & \multicolumn{2}{|c|}{ WB/EBB cohort (2004) } & \multicolumn{2}{|c|}{ Pooled } \\
\hline & Coefficient & Absolute $\mathrm{t}$ & Coefficient & Absolute t & Coefficient & Absolute t \\
\hline & $(1)$ & $(2)$ & (3) & $(4)$ & (5) & (6) \\
\hline \multicolumn{7}{|l|}{ Employer match } \\
\hline \multicolumn{7}{|l|}{ No match (omitted) } \\
\hline Match & 0.012 & 0.40 & 0.019 & 0.39 & 0.010 & 0.39 \\
\hline Match missing & 0.049 & 1.09 & -0.033 & 0.53 & 0.021 & 0.58 \\
\hline \multicolumn{7}{|l|}{ Investment choice } \\
\hline Has investment choice & $-0.154^{* *}$ & 2.11 & $-0.206^{* * *}$ & 2.75 & $-0.124^{* * *}$ & 2.9 \\
\hline \multicolumn{7}{|c|}{ DC account balance at interview (in \$2004) } \\
\hline \multicolumn{7}{|l|}{0 - 9,999 (omitted) } \\
\hline $10,000-49,999$ & $-0.099^{* * *}$ & 2.88 & -0.050 & 0.87 & $-0.084^{* * *}$ & 2.9 \\
\hline 50,000 or more & $-0.086^{* *}$ & 1.93 & -0.003 & 0.05 & -0.049 & 1.44 \\
\hline Missing & 0.002 & 0.05 & 0.146 & 0.69 & 0.025 & 0.72 \\
\hline \multicolumn{3}{|c|}{ How account balance is invested } & \multicolumn{4}{|c|}{ Mostly stock (omitted) } \\
\hline Mostly bond & -0.020 & 0.47 & -0.010 & 0.20 & -0.008 & 0.26 \\
\hline Evenly split & -0.031 & 0.87 & 0.024 & 0.63 & -0.010 & 0.37 \\
\hline Missing & -0.121 & 1.60 & -0.018 & 0.25 & -0.071 & 1.47 \\
\hline \multicolumn{7}{|l|}{ Household assets } \\
\hline Has IRA/Keogh & -0.047 & 1.60 & -0.053 & 1.44 & $-0.043^{*}$ & 1.87 \\
\hline Holds stock & -0.031 & 1.08 & 0.040 & 1.01 & -0.017 & 0.73 \\
\hline \multicolumn{6}{|c|}{ Household wealth quartiles (\$2004) } & First (omitted) \\
\hline Second & $0.071^{*}$ & 1.91 & 0.059 & 1.19 & $0.064^{* *}$ & 2.14 \\
\hline Third & 0.050 & 1.27 & -0.012 & 0.23 & 0.024 & 0.74 \\
\hline Fourth & 0.062 & 1.38 & -0.019 & 0.33 & 0.029 & 0.82 \\
\hline \multicolumn{7}{|c|}{$\begin{array}{l}\text { W-2 Annual earnings quartiles (\$2003) } \\
\text { First (omitted) }\end{array}$} \\
\hline Second & 0.004 & 0.11 & 0.014 & 0.28 & 0.006 & 0.21 \\
\hline Third & -0.051 & 1.16 & 0.033 & 0.58 & -0.027 & 0.79 \\
\hline Fourth & -0.030 & 0.60 & -0.038 & 0.60 & -0.031 & 0.78 \\
\hline Cohort (WB/EBB =1) & --- & --- & --- & --- & $-0.067^{* *}$ & 2.28 \\
\hline Constant & $0.487^{* * *}$ & 4.04 & $0.567^{* * *}$ & 3.97 & $0.467^{* * *}$ & 5.32 \\
\hline Mean of dependent variable & \multicolumn{2}{|c|}{0.362} & \multicolumn{2}{|c|}{0.297} & \multicolumn{2}{|c|}{0.345} \\
\hline Prob $>F$ & \multicolumn{2}{|c|}{0.014} & \multicolumn{2}{|c|}{0.035} & \multicolumn{2}{|c|}{0.0001} \\
\hline Adjusted $\mathrm{R}^{2}$ & \multicolumn{2}{|c|}{0.030} & \multicolumn{2}{|c|}{0.073} & \multicolumn{2}{|c|}{0.043} \\
\hline $\mathrm{N}$ of Obs & \multicolumn{2}{|c|}{762} & \multicolumn{2}{|c|}{260} & \multicolumn{2}{|c|}{1,022} \\
\hline
\end{tabular}

Note: See notes in Table 4.

${ }^{\text {a }}$ Dependent variable is measured as the absolute difference between the self-reported and W-2 record contributions, divided by the larger value.

${ }^{\mathrm{b}}$ Not reported are the coefficients for additional controls for missing values due to small sample sizes (less than 30 in either or both cohorts).

${ }^{*}, * *$, and ${ }^{* * *}$ denote significance at the 10,5 , and 1 percent level, respectively. 


\begin{tabular}{|c|c|c|c|c|c|c|c|c|}
\hline \multirow{2}{*}{ Cohort } & \multirow{2}{*}{ Birth Year } & \multicolumn{7}{|c|}{ Interview year } \\
\hline & & 1992 & 1994 & 1996 & 1998 & 2000 & 2002 & 2004 \\
\hline \multirow{2}{*}{ HRS } & 1931-1935 & $57-61$ & $59-63$ & $61-65$ & $63-67$ & $65-69$ & $67-71$ & $69-73$ \\
\hline & 1936-1941 & $51-56$ & 53-58 & $55-60$ & $57-62$ & $59-64$ & 61-66 & $63-68$ \\
\hline WB & $1942-1947$ & & & & $51-56$ & 53-58 & $55-60$ & $57-62$ \\
\hline EBB & 1948-1953 & & & & & & & $51-56$ \\
\hline
\end{tabular}

Note: Numbers in each row indicate ages of three birth cohorts at each wave throughout the survey.

\section{Appendix Table 2. Sample sizes of consenters in the HRS and WB/EBB cohorts}

\begin{tabular}{|c|c|}
\hline Overall HRS cohort & 10,093 \\
\hline Overall WB cohort & 1,812 \\
\hline Overall EBB cohort & 1,626 \\
\hline HRS Cohort: ages 51-61 in 1992 & 7,857 \\
\hline 1992 consent & 4,004 \\
\hline 2004 consent $^{1}$ & 3,853 \\
\hline WB/EBB Cohort: ages 51-61 in 2004 & 2,754 \\
\hline WB Total ${ }^{2}$ & 1,448 \\
\hline 1998 consent & 1,086 \\
\hline 2004 consent & 362 \\
\hline EBB Total & 1,306 \\
\hline
\end{tabular}

Notes: Authors' calculations using data from the Health and Retirement Study and Social Security earnings records. Respondents in the Health and Retirement Study were asked either in 1992, 1998, or 2004 to give permission to link their survey information with Social Security administrative records. The original HRS cohort, first interviewed in 1992, was asked for permission in 1992 and again in 2004. Additional permissions were obtained in 1994 and 1996; we refer to all 1992-1996 permissions as 1992 consents. The WB cohort, first interviewed in 1998, was asked to give permission in 1998; those who refused were asked again in 2004. The EBB cohort was asked to give permission when first interviewed in 2004.

\footnotetext{
${ }^{1}$ The majority of these respondents gave consents in 1992 as well as in 2004.

${ }^{2}$ For this cohort, we use only the subset of consenters who gave permissions in 2004 because only for them can we compare their survey reports in 2004 with W-2 reports for year 2003. For WB respondents who gave consents in 1998, information on tax-deferred contributions is available only up to 1997.
} 
Appendix Table 3. Sample means by cohort

\begin{tabular}{|c|c|c|}
\hline Characterisitcs & $\begin{array}{c}\text { HRS cohort } \\
\text { (1992) }\end{array}$ & $\begin{array}{c}\text { WB/EBB } \\
\text { cohort (2004) }\end{array}$ \\
\hline Female & 0.47 & 0.45 \\
\hline $\begin{array}{l}\text { Age } \\
51-53 \\
54-56 \\
57-61\end{array}$ & $\begin{array}{l}0.32 \\
0.32 \\
0.36\end{array}$ & $\begin{array}{l}0.49 \\
0.37 \\
0.14\end{array}$ \\
\hline $\begin{array}{l}\text { Race } \\
\text { White } \\
\text { Black } \\
\text { Hispanic }\end{array}$ & $\begin{array}{l}0.84 \\
0.09 \\
0.07\end{array}$ & $\begin{array}{l}0.86 \\
0.09 \\
0.05\end{array}$ \\
\hline $\begin{array}{l}\text { Education } \\
\text { High school grad or less } \\
\text { Some college } \\
\text { College graduate }\end{array}$ & $\begin{array}{l}0.49 \\
0.25 \\
0.26\end{array}$ & $\begin{array}{l}0.34 \\
0.33 \\
0.33\end{array}$ \\
\hline $\begin{array}{l}\text { Marital Status } \\
\text { Married }\end{array}$ & 0.80 & 0.78 \\
\hline $\begin{array}{l}\text { Health Status } \\
\text { Fair/poor } \\
\text { Good } \\
\text { Excellent/very good }\end{array}$ & $\begin{array}{l}0.08 \\
0.29 \\
0.63\end{array}$ & $\begin{array}{l}0.16 \\
0.23 \\
0.61\end{array}$ \\
\hline $\begin{array}{l}\text { Financial planning horizon } \\
\text { Next year or less } \\
2 \text { to } 5 \text { years } \\
\text { More than } 5 \text { years } \\
\text { Financial planning missing }\end{array}$ & $\begin{array}{l}0.17 \\
0.34 \\
0.47 \\
0.02\end{array}$ & $\begin{array}{l}0.14 \\
0.25 \\
0.57 \\
0.04\end{array}$ \\
\hline $\begin{array}{l}\text { Risk Aversion } \\
\text { Least risk averse } \\
\text { Somewhat risk averse } \\
\text { Most risk averse } \\
\text { Risk missing }\end{array}$ & $\begin{array}{l}0.09 \\
0.22 \\
0.67 \\
0.03\end{array}$ & $\begin{array}{l}0.10 \\
0.28 \\
0.54 \\
0.08\end{array}$ \\
\hline $\begin{array}{l}\text { Expected Years to Retirement } \\
6 \text { years or less } \\
7 \text { to } 12 \text { years } \\
\text { More than } 12 \text { years } \\
\text { Never } \\
\text { Don't know }\end{array}$ & $\begin{array}{l}0.37 \\
0.41 \\
0.10 \\
0.07 \\
0.05\end{array}$ & $\begin{array}{l}0.09 \\
0.27 \\
0.15 \\
0.44 \\
0.05\end{array}$ \\
\hline
\end{tabular}


Appendix Table 3 (cont.)

\begin{tabular}{|c|c|c|}
\hline Characterisitcs & $\begin{array}{c}\text { HRS cohort } \\
\text { (1992) }\end{array}$ & $\begin{array}{c}\mathrm{WB} / \mathrm{EBB} \\
\text { cohort (2004) }\end{array}$ \\
\hline \multicolumn{3}{|l|}{ Occupation } \\
\hline Blue-collar worker & 0.33 & 0.31 \\
\hline Managerial & 0.39 & 0.41 \\
\hline White-collar worker & 0.28 & 0.28 \\
\hline \multicolumn{3}{|l|}{ Tenure (years) } \\
\hline Less than 6 & 0.15 & 0.19 \\
\hline $6-15$ & 0.34 & 0.40 \\
\hline 16 or more & 0.51 & 0.41 \\
\hline \multicolumn{3}{|l|}{ Employer match } \\
\hline No match & 0.24 & 0.18 \\
\hline Match & 0.64 & 0.67 \\
\hline Match missing & 0.12 & 0.15 \\
\hline \multicolumn{3}{|l|}{ Investment choice } \\
\hline Has investment choice ${ }^{1}$ & 0.68 & 0.94 \\
\hline \multicolumn{3}{|c|}{ DC account balance at interview } \\
\hline $0-9,999$ & 0.28 & 0.13 \\
\hline $10,000-49,999$ & 0.35 & 0.28 \\
\hline 50,000 or more & 0.19 & 0.58 \\
\hline Missing & 0.18 & 0.01 \\
\hline \multicolumn{3}{|c|}{ How account balance is invested } \\
\hline Mostly stock & 0.20 & 0.43 \\
\hline Mostly bond & 0.16 & 0.13 \\
\hline Evenly split & 0.28 & 0.36 \\
\hline Missing & 0.36 & 0.08 \\
\hline \multicolumn{3}{|l|}{ Household assets } \\
\hline Has IRA/Keogh & 0.57 & 0.49 \\
\hline Holds stock & 0.43 & 0.34 \\
\hline Household wealth $^{2}$ & $\begin{array}{c}263,543 \\
(421,364)\end{array}$ & $\begin{array}{c}261,578 \\
(319,493)\end{array}$ \\
\hline Annual earnings & $\begin{array}{c}47,592 \\
(26,115)\end{array}$ & $\begin{array}{c}54,043 \\
(37,800)\end{array}$ \\
\hline N. of Obs. & 762 & 260 \\
\hline
\end{tabular}

Notes : Authors' calculations using data from the HRS. See notes in Table 4. Standard deviations in parentheses.

${ }^{1}$ In the overall sample 45 percent of respondents in the HRS cohort and 60 percent of respondents in the WB/EBB cohort have investment choices. The rates are higher in these samples due to their selectivity.

${ }^{2}$ Excludes DC account balances with current employer. 